\title{
25. DOWNHOLE FLOW OF BOTTOM WATER: IMPLICATIONS FROM TEMPERATURE LOGGING AT HOLE 462A, NAURU BASIN, DEEP SEA DRILLING PROJECT LEG 891
}

\author{
Naoyuki Fujii, Department of Earth Sciences, Kobe University, Japan ${ }^{2}$
}

\begin{abstract}
Temperature logging at Hole $462 \mathrm{~A}$, which has remained undisturbed for $4 \frac{1}{4}$ years after drilling, reveals a very small temperature increase from $1.3^{\circ} \mathrm{C}$ at the seafloor to $3.9^{\circ} \mathrm{C}$ at $400 \mathrm{~m}$ sub-bottom depth, followed by a steep increase to $24^{\circ} \mathrm{C}$ at $500 \mathrm{~m}$. This temperature gradient strongly indicates downhole flow of bottom water into the sediments between 400 and $500 \mathrm{~m}$ below the seafloor at the time of Leg 89 . The downhole flow of bottom water is probably caused by the underpressure in the 70-Ma sediments of the Nauru Basin; this is in contrast to other DSDP holes with similar downhole flow phenomena, such as 395A and 504B, where the bottom water permeates into the underpressured young basaltic basements by hydrothermal circulation. By assuming a constant flow rate of bottom water and a linear temperature gradient of $0.045^{\circ} \mathrm{C} / \mathrm{m}$ for undisturbed sediments, the volumetric downhole flow rate is calculated to be about $1700 \mathrm{~L} /$ $\mathrm{hr}$ (or $6 \mathrm{~m} / \mathrm{hr}$. linear rate). For $4 \frac{1}{4} 4$ years, at least $6 \times 10^{7} \mathrm{~kg}$ of seawater has been drawn down through the drilled hole into the sediments. The heat-flow value of $48 \mathrm{~mW} / \mathrm{m}^{2}$ for undisturbed sediments at Site 462 is concordant with the intraplate volcanism about $100 \mathrm{Ma}$ in the Pacific Plate.
\end{abstract}

\section{INTRODUCTION}

The plate age predicted for the position of Site 462 in the Nauru Basin is about $150 \mathrm{Ma}$, that is, on the older boundary of magnetic anomaly M-26. At Site 462 , a sediment layer about $560 \mathrm{~m}$ thick is underlain by basaltic sills and flows associated with the intraplate volcanism that occurred about $100 \mathrm{Ma}$ (Larson and Schlanger, 1981). Because extensive intraplate volcanism took place in the mid-Pacific region, including the Naru Basin, some deviations from a simple cooling-plate model are expected for heat-flow values, subsidence, and sedimentation history of the possibly "Jurassic" deep oceanic basins (e.g., Schlanger, et al., 1981).

During DSDP Leg 61 in 1978, downhole temperatures in Hole 462 were measured using the Tokyo T-probe in sediments ahead of the bit during the drilling (Yokota et al., 1980) and the Gearhart-Owen continuous T-logs (GOHRT) after the drilling (Larson, Schlanger, et al., 1981). For sediments down to about $250 \mathrm{~m}$ sub-bottom in Hole 462 , two continuous T-logs after the drilling indicate extrapolated equilibrium temperatures about 2 to $5^{\circ} \mathrm{C}$ lower than those recorded in good data from the Tokyo T-probe. Because of this discrepancy between the two measurements, the heat-flow value at the Naru Basin has not been determined (Boyce, 1981). From extrapolated equilibrium temperature gradients, which showed no increase or even decrease in basaltic sills at about 600 to $700 \mathrm{~m}$ sub-bottom (Fig. 1), Boyce (1981) suggested that convection of water into basaltic layers might cause such anomalous temperatures if the data were representative of in situ conditions.

Downhole flow of bottom water through artificial holes is suggested to occur at several DSDP holes including

\footnotetext{
${ }^{1}$ Moberly, R., Schlanger, S. O., et al., Init. Repts. DSDP, 89: Washington (U.S. Govt. Printing Office).

2 Address: Dept. of Earth Sciences, Nada, Kobe University, Kobe 657, Japan.
}

Hole 454A in the Mariana Trough (Uyeda and Horai, 1982), Holes 335, 396B, and 395A on the Mid-Atlantic Ridge (Hyndman et al., 1977; Erickson and Hyndman, 1978; Becker et al., 1984), and Hole 504B on the Costa Rica Rift (Becker, Langseth, and Von Herzen, 1983; Becker, Langseth, Von Herzen, and Anderson, 1983; Becker et al., in press), though flow rates were obtained only for Holes 395A and 504B. All these holes are located near a seafloor spreading axis, where hydrothermal circulation is expected in the young basaltic basements.

By using results of the Leg 89 temperature logging, a rate of bottom-water downflow is estimated for Hole $462 \mathrm{~A}$ by assuming a constant flow rate and a linear undisturbed thermal gradient as measured on Leg 61 .

\section{METHOD AND OPERATION}

Borehole temperatures in Hole 462A were logged using the Schlumberger high-resolution temperature logging tool (S-HRT). Hole $462 \mathrm{~A}$ was offset about $460 \mathrm{~m}$ north-northwest of Hole 462 , where temperatures were measured during Leg 61 . The reentry cone and $75-\mathrm{m}-$ long bottom assembly used in Hole $462 \mathrm{~A}$ were left undisturbed after the drilling had stopped on 25 July 1978 . Lowering of the S-HRT began at $0300 \mathrm{hr}$. on 7 November 1982 and ended at $0700 \mathrm{hr}$.; this was the first operation after the drill string had reentered. The logging tool, lowered at slow winch speed (about $0.3 \mathrm{~m} / \mathrm{s}$ ), met with slight obstructions at 470 and $515 \mathrm{~m}$ sub-bottom and blocked at $521 \mathrm{~m}$, probably as a result of a slight blockage of slumped sediments or a discontinuous change of hole diameter, because no difficulty was encountered in the course of cleaning out the hole down below $500 \mathrm{~m}$ by using the drill string.

The S-HRT was calibrated several times using a standard mercury thermometer at 0.8 and $25.5^{\circ} \mathrm{C}$ before and after the logging. Because of the short time-constant of the S-HRT probe $(<30 \mathrm{~s}$; Becker, Langseth, Von Herzen, and Anderson, 1983), the delay in the response of this probe can be ignored at slow winch speeds.

\section{RESULTS AND INTERPRETATION}

Temperatures obtained by the S-HRT show a very small increase from $1.3^{\circ} \mathrm{C}$ at the seafloor to $3.9^{\circ} \mathrm{C}$ at $395 \mathrm{~m}$ sub-bottom, and the temperature gradient increases gradually with depth. Below $400 \mathrm{~m}$, temperatures rise rapidly 
to about $24^{\circ} \mathrm{C}$ at $500 \mathrm{~m}$, as shown in Figure 1 (solid curve).

For the depth interval with steep temperature gradient, the actual temperature record indicates some fluctuation, with an amplitude of as much as about $1^{\circ} \mathrm{C}$ (figure 21 of the Site 462 report, this volume). Although a 1-m long sinker bar ahead of the S-HRT probe would generate local mixing of water (Becker et al., in press), this fluctuation of temperature must be due to the upand-down motion of the logging tool, because the fluctuation varies coherently with the simultaneously recorded tension of the cable. If the fluctuation corresponds to the heave-related motion of the probe relative to the hole wall, the time constant of S-HRT is sufficiently short that no correction for the delay of this probe seems justified.

The temperature distribution in this hole is very similar to that in DSDP holes where downflow rates of seawater have been estimated, such as Holes 504B (Becker, Langseth, and Von Herzen, 1983; Becker, Langseth, Von Herzen, and Anderson, 1983; Becker et al., in press) and 395A (Becker et al., 1984). Because the extrapolation (Boyce, 1981) of equilibrium temperatures from the two GO-HRT logs assumes no movement of water in the hole, the discrepancy between the bottom-hole temperatures and extrapolated equilibrium temperatures suggests water movement in the hole after drilling stopped. Both observations strongly indicate that the downflow of seawater has continued for the $4 \frac{1}{4}$ years since Hole $462 \mathrm{~A}$ was drilled. A simple extension of the temperature gradient obtained by the Tokyo T-probe seems consistent with the S-HRT record at $500 \mathrm{~m}$ (Fig. 1). A nearly constant temperature gradient of $0.045^{\circ} \mathrm{C} / \mathrm{m}$ in the upper $220 \mathrm{~m}$, obtained from good data of the bottom-hole temperature measurements, can be taken to represent the undisturbed sediment temperatures at this site. Using $1.07 \mathrm{~W} / \mathrm{m}^{\circ} \mathrm{C}$ for the thermal conductivity of the sediments (Larson, Schlanger, et al., 1981), the undisturbed heat flow becomes about $48 \mathrm{~mW} / \mathrm{m}^{2}$ for Site 462 .

Assuming a linear temperature gradient, $G$, for undisturbed sediments and a constant linear flow rate in the hole, $U$, the temperature, $T$, as a function of depth, $z$, can be expressed as (Becker, Langseth, and Von Herzen, 1983)

$$
T(z)=T_{s}+G \cdot z-G \cdot[1-\exp (-A \cdot z)] / A
$$

and

$$
A=8 K I(x) /\left(\pi^{2} a^{2} C U\right)
$$

where $T_{s}$ is the temperature at the seafloor, $K$ is the thermal conductivity of the sediments, $a$ is the radius of the hole, and $C$ is the heat capacity of seawater per unit volume. Jaeger (1965) has tabulated the values of an integral involving Bessel functions, $I(x)$, in which $x$ is $k t / a^{2}$ ( $k$ is the thermal diffusivity of the sediments and $t$ is the elapsed time after the commencement of flow).

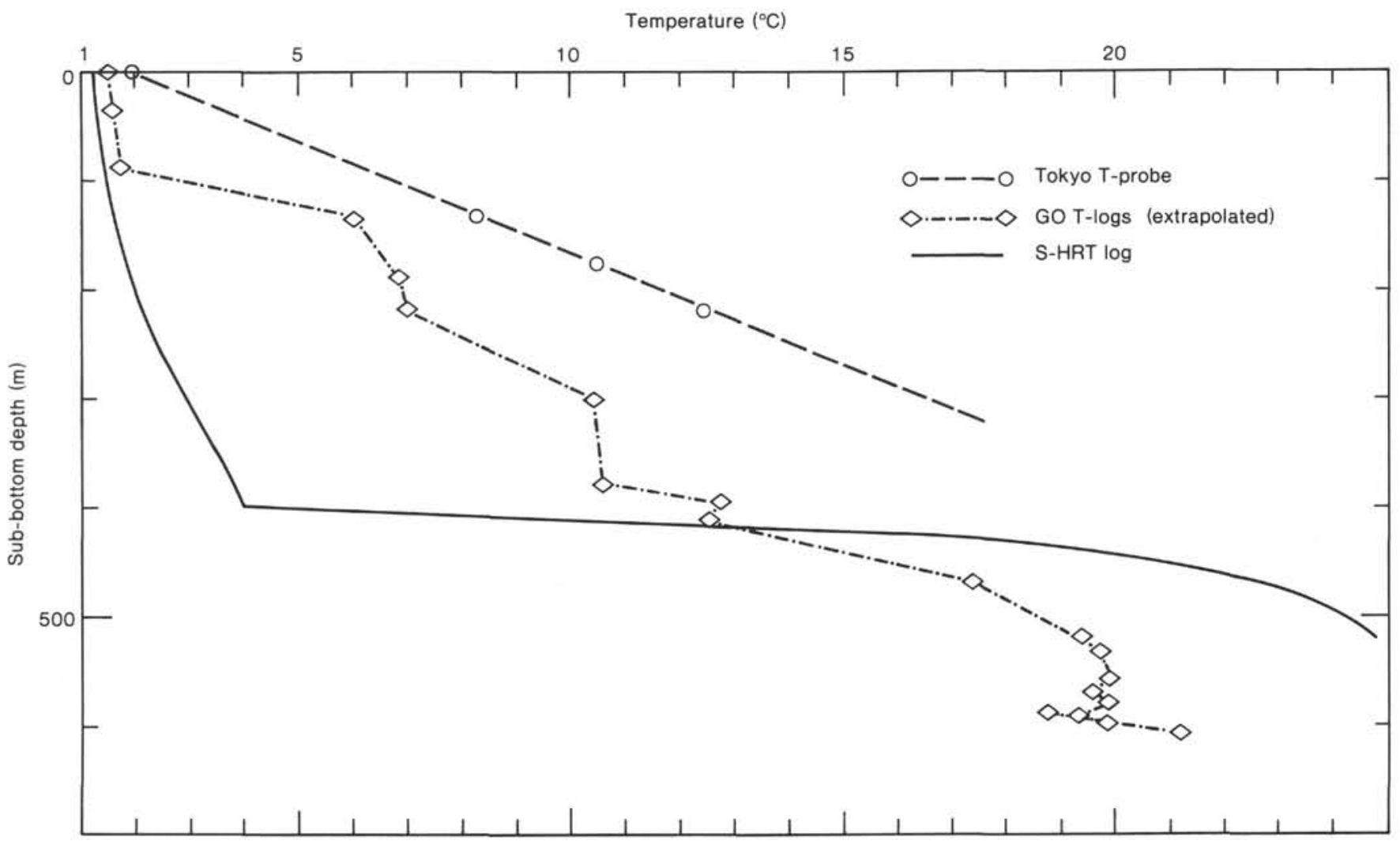

Figure 1. Borehole temperatures measured in the upper part of Hole 462 (broken line) using the Tokyo T-probe during drilling of sediments (Leg 61) and in Hole 462A (solid curve) using the S-HRT (Leg 89). Dotted curve indicates equilibrium temperatures extrapolated from the two GO-HRT logs taken after Hole 462 was drilled (Leg 61). Leg 61 data are from Boyce (1981). 
By fitting the obtained temperatures down to $395 \mathrm{~m}$ sub-bottom depth with calculated ones, where constants used are $C=1 \mathrm{cal} / \mathrm{cm}^{3}, k=0.005 \mathrm{~cm}^{2} / \mathrm{s}, G=$ $0.045^{\circ} \mathrm{C} / \mathrm{m}, a=30 \mathrm{~cm}$ and $t=1550$ days, the downflow rate, $U$, is obtained as $6 \mathrm{~m} / \mathrm{hr}$. $(1.7 \mathrm{~mm} / \mathrm{s})$, which translates to a volumetric rate of $1700 \mathrm{~L} / \mathrm{hr}$. (Fig. 2). Because the variation of the value of $I(x)$ in Equation (2) becomes small for the long time elapsed after drilling, the ambiguity of the hole diameter does not largely affect the result for the volumetric downflow rate $\left(\approx a^{2} U\right)$. For example, a reduction of $a$ by half (say, from 40 to $20 \mathrm{~cm}$ ) results only in about a $40 \%$ decrease.

The layer of a steep temperature rise (400-500 m subbottom) would correspond to an underpressured reservoir where the bottom water penetrated radially. Although the origin and cause of the underpressure in this layer remain unknown, it is probable that the downhole flow would decrease with time, as evidenced in Hole 504B (Becker, Langseth, Von Herzen, and Anderson, 1983; Becker et al., in press). If a similar mechanism holds in Hole $462 \mathrm{~A}$, it is estimated that at least $6 \times 10^{7} \mathrm{~kg}$ of seawater has been drawn down through the hole and penetrated into sediments for $4 \frac{1}{4}$ years in the Nauru Basin.

\section{DISCUSSION AND IMPLICATIONS}

The heat-flow value of $48 \mathrm{~mW} / \mathrm{m}^{2}$ calculated for Site 462 is slightly higher than that expected from a "root- $t$ " decrease curve of a normal oceanic basin. It seems concordant, however, that the temperature structure was affected by the intraplate volcanism about 70 to $110 \mathrm{Ma}$

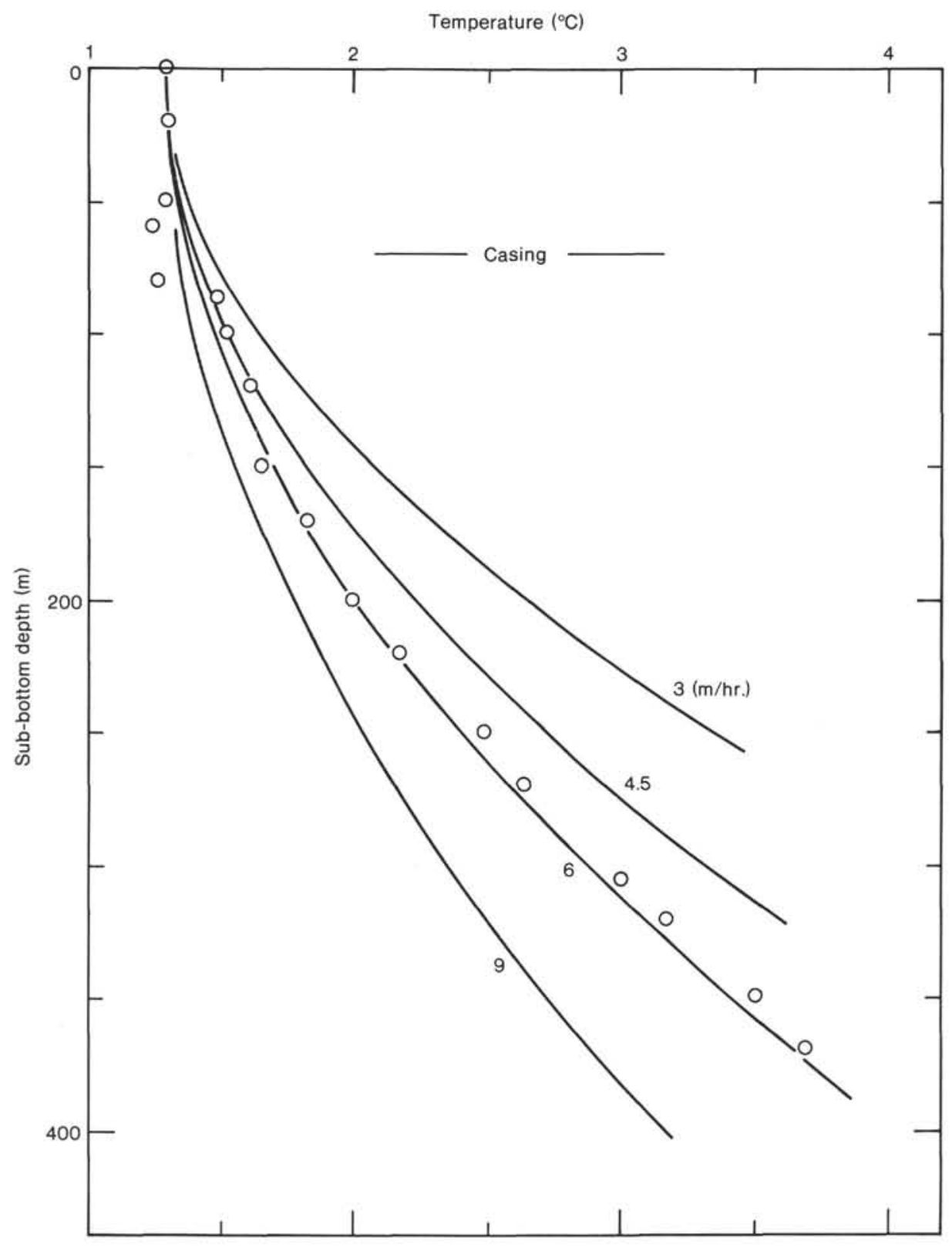

Figure 2. Observed temperatures and theoretical curves at 1550 days, Hole $462 \mathrm{~A}$. Flow rate of $6 \mathrm{~m} / \mathrm{hr}$. corresponds to volumetric flow rate of $1.7 \mathrm{~kL} / \mathrm{hr}$. 
(Schlanger et al., 1981), so that the heat-flow value obtained is similar to values for approximately 100-Ma ocean crust in the Pacific (Parsons and Sclater, 1977).

The downhole flow rate obtained is of an order of magnitude similar to those for previously estimated DSDP holes (395A and 504B, as listed in Table 1). In the Naru Basin, the downhole flow of seawater probably resulted from underpressures in the sediments of age up to about $70 \mathrm{Ma}$, rather than in young basaltic basements in other DSDP holes with downhole flow phenomena. If the radial flow through the hole wall is controlled by Darcy's Law, the pressure difference between the underpressured reservoir and the hole is high enough between 400 and $520 \mathrm{~m}$ sub-bottom. From only the temperature measurements, a small amount of radial flow in the upper part of the layer cannot be resolved, so that the upper boundary of the reservoir may not be fixed at $400 \mathrm{~m}$ sub-bottom but may depend on time, as evidenced in Hole 504B (Becker et al., in press). The permeability of sediments generally decreases with depth, and it changes by orders of magnitude. In the underpressured reservoir in this depth range, where the lithology is lower Eocene to middle Maestrichtian chert and limestone or lower Maestrichtian to upper Campanian volcaniclastic sediments (Larson, Schlanger, et al., 1981), the permeability of sediments is likely to be high.

Although permeabilities of sediments and basaltic sills and flows at Site 462 were not measured, there remains a possibility that mixtures of chert and limestone or volcaniclastic sediments could have higher permeabilities than younger sediments (Morin and Silva, 1984). A sediment layer about $400 \mathrm{~m}$ thick could not hold underpressures for more than about $10^{5}$ yrs. (Becker, Langseth, and Von Herzen, 1983), if the permeability of these sediments is $10^{-14}$ to $10^{-17} \mathrm{~m}^{2}$, (Bryant et al., 1974). This would seem to rule out the possibility that the under-

Table 1. Characteristics of DSDP Holes for which the downflow rates have been estimated.

\begin{tabular}{|c|c|c|c|}
\hline & $395 \mathrm{~A}^{\mathrm{a}}$ & $504 \mathrm{~B}^{\mathrm{b}}$ & $462 A^{c}$ \\
\hline Latitude & $22^{\circ} 45.35^{\prime} \mathrm{N}$ & $01^{\circ} 13.62^{\prime} \mathrm{S}$ & $07^{\circ} 14.50^{\prime} \mathrm{N}$ \\
\hline Longitude & $46^{\circ} 04.90^{\prime} \mathrm{W}$ & $80^{\circ} 43.82^{\prime} \mathrm{W}$ & $165^{\circ} 01.90^{\prime} \mathrm{E}$ \\
\hline Seafloor depth (m) & $\begin{array}{c}4483 \\
\text { Leg } 45: 610\end{array}$ & $\begin{array}{r}3460 \\
\text { Leg } 69: 489\end{array}$ & $\begin{array}{c}5177 \\
.0261 \cdot 1069\end{array}$ \\
\hline Sub-bottom depth (m) & Leg 78B: 610 & $\begin{array}{l}\text { Leg 69: } 489 \\
\text { Leg 70: } 835 \\
\text { Leg 83: } 1287.5 \\
\text { Leg 92: } 1350\end{array}$ & Leg 89: 1209 \\
\hline Sediment thickness (m) & 90 & 274.5 & 560 \\
\hline Casing depth $(m)$ & 100 & 300 & $75^{\mathrm{d}}$ \\
\hline $\begin{array}{l}\text { Bottom depth of } \\
\text { downhole flow (m) }\end{array}$ & $\begin{array}{c}>100 \\
(250-500)^{\mathrm{e}}\end{array}$ & $320-400$ & $400-500$ \\
\hline Reservoir (age, Ma) & Basalts (7.3) & Basalts (6.2) & Sediments $(70-80)$ \\
\hline Seafloor age (Ma) & 7.3 & 6.2 & $>110$ \\
\hline Downflow rate $(\mathrm{kL} / \mathrm{hr}$ ) & Leg 78B: $>1(5)^{f}$ & $\begin{array}{l}\text { Leg 70: } 6(1 / 7)^{\mathrm{f}} \\
\text { Leg 83: } 1.7(2)^{\mathrm{f}} \\
\text { Leg 92: } 0.17(3.5)^{\mathrm{f}}\end{array}$ & Leg 89: $1.7(4.25)^{f}$ \\
\hline $\begin{array}{l}\text { Undisturbed heat } \\
\text { flow }\left(\mathrm{mW} / \mathrm{m}^{2}\right)\end{array}$ & $\begin{array}{l}49 \\
378\end{array}$ & 200 & 48 \\
\hline Temp. gradient $\left({ }^{\circ} \mathrm{C} / \mathrm{km}\right)$ & $\begin{array}{l}85 \\
288\end{array}$ & $114-200$ & 45 \\
\hline
\end{tabular}

a Becker et al. (1984).

b Becker, Langseth, and Von Herzen (1983); Becker, Langseth, Von Herzen and Anderson (1983); Becker et al. (in press).

c This work.

d Depth of bottom hole assembly; no casing was emplaced.

e Estimated high permeability rock layer.

Lapsed time after drilling (in years)

$g$ Estimated from nearby usual heat-flow measurements. pressures might be a relict of pressure decrease caused by cellular hydrothermal circulation confined to the lower part of sediments or by subsidence of the cooling plate which had been reheated by mid-plate volcanism. Whatever mechanism causes underpressures in the sediments, it must be active now in the Nauru Basin.

If the 400-m-thick sediments do not contribute to the overpressure, the hydrostatic pressure of a cold water column $\left(\sim 4^{\circ} \mathrm{C}\right)$ in the hole would cause the excess pressure relative to the hot undisturbed sediments $\left(\sim 25^{\circ} \mathrm{C}\right)$. The excess pressure at $500 \mathrm{~m}$ sub-bottom becomes less than $0.1 \mathrm{bar}$, because the average density difference becomes about $0.002 \mathrm{~g} / \mathrm{cm}^{3}$ for the same salinity, provided that the pore pressure of undisturbed sediments is hydrostatic. The required permeability of sediments in the underpressured reservoir becomes about 0.1 darcy $\left(10^{-13} \mathrm{~m}^{2}\right)$ for the downhole flow rate of $6 \mathrm{~m} / \mathrm{hr}$., a 100 -m-thick reservoir, and $4 \frac{1 / 4}{4}$ yrs., provided that the radial flow of water obeys the pressure-diffusion equation (Becker, Langseth, and Von Herzen, 1983). The fact that Hole 462A has remained open for $4 \frac{1}{4}$ years without casing below the bottom-hole assembly suggests that there is no apparent deformation of sediments, and may support the assumption that the pore pressure in the 400 -m-thick sediments does not exceed hydrostatic pressure. It may be that the permeability of sediments gradually decreases with depth down to $400 \mathrm{~m}$ sub-bottom and then increases abruptly to generate a dominant radial flow through the hole wall. At about $500 \mathrm{~m}$ sub-bottom, the excess pressure tends to diminish as a result of both decreased permeability and reduced temperature difference.

However, the forced radial flow of bottom water into the aquifer, resulting from the excess pressure of the cold water column, may not cause a significant downflow of seawater into the sediments, unless the permeability of this layer is about 0.1 darcy, which is nearly the same order of magnitude as the permeability of the basaltic basement (Zoback and Anderson, 1983). To check the applicability of this mechanism, estimates of the permeability of the sediments and the pore-pressure distribution are obviously desired for in situ downhole measurements.

Although the downhole flow phenomenon is not a direct consequence of hydrothermal activity, DSDP holes previously suggested to have downhole flow of bottom water are generally in regions where hydrothermal circulation is expected in the basaltic basements (Anderson and Zoback, 1982; Zoback and Anderson, 1983; Langseth et al., 1984). In general, the underpressured region is expected to be far larger than the overpressured region, where the upwelling of pore fluid through artificial holes could occur, as suggested by Duennebier and Blackinton (1980). From Site 462, the nearest seamount is Ujao Atoll, in the Marshall seamounts, about $200 \mathrm{~km}$ to the northeast, and Kusae Island is about $350 \mathrm{~km}$ to the southwest. It is unlikely that hydrothermal circulation similar to that expected in the small (several kilometers wide) sediment pond at Site 395 near the Mid-Atlantic Ridge (Langseth et al., 1984) is active now in the Nauru Basin.

There remains a possibility that hydrothermal activity may be continuing in the Nauru Basin (1) if condi- 
tions there are similar to those of the exceptionally anomalous high heat flow observed in the 80-Ma crust in the northwest Atlantic (Embley et al., 1983), or (2) if sources of basin-filled sills and flows are still active or contributing to the pore-water circulation but the probable mechanism is undeniably the excess pressure caused by the cold water column of the artificially drilled hole. A more detailed heat-flow survey of old ocean basins such as the Nauru Basin should be made.

Although the cause of underpressure in the sediments beneath Hole 462A remains unknown, the downhole flow of bottom water seems a common phenomenon in the DSDP holes that have been left open for a long time. Further investigations of physical properties are obviously needed in deep holes in old oceanic basins, as well as in those near the diverging plate boundary.

\section{ACKNOWLEDGMENTS}

The author thanks R. Moberly, S. Schlanger (Co-Chief Scientists), and other colleagues of Leg 89 for their interest and encouragement. G. Foss and J. Noaks greatly contributed to the temperature logging. Drs. Kier Becker and R. P. Von Herzen incisively reviewed an earlier version of this paper. Dr. K. Becker kindly sent me a preprint which contributed greatly toward improving the manuscript. Typing assistance by $\mathrm{H}$. Wada and J. Asakura was helpful. This work was supported in part by the Japanese IPOD Committee and a grant from the Ministry of Education, Science and Culture, Japan.

\section{REFERENCES}

Anderson, R. N., Honnorez, J., Becker, K., Adamson, A. C., Alt, J. C., et al., 1982. DSDP Hole 504B, the first reference section over $1 \mathrm{~km}$ through Layer 2 of the oceanic crust. Nature, 300:589-594.

Anderson, R. N., and Zoback, M. D., 1982. Permeability, underpressures, and convection in the oceanic crust near the Costa Rica Rift, eastern equatorial Pacific. J. Geophys. Res., 87:2860-2868.

Becker, K., Langseth, M. G., and Hyndman, R. D., 1984. Temperature measurements in Hole 395A, Leg 78B. In Hyndman, R. D., Salisbury, M. H., et al., Init. Repts. DSDP, 78B: Washington (U.S. Govt. Printing Office), 689-698.

Becker, K., Langseth, M. G., and Von Herzen, R., 1983. Deep crustal geothermal measurements, Hole 504B, DSDP Legs 69 and 70. In Cann, J. R., Langseth, M. G., Honnorez, J., Von Herzen, R. P., White, S. M., et al., Init. Repts. DSDP, 69: Washington (U.S. Govt. Printing Office), 223-236.

Becker, K., Langseth, M. G., Von Herzen, R., and Anderson, R. N., 1983. Deep crustal geothermal measurements, Hole 504B. J. Geophys. Res., 88:3447-3457.

Becker, K., Langseth, M. G., Von Herzen, R. P., Anderson, R. N., and Hobart, M., in press. Deep crustal geothermal measurements, Hole 504B, DSDP Legs 69, 70, 83, and 92. In Anderson, R. N., Honnorez, J., Becker, K., et al., Init. Repts. DSDP, 83: Washington (U.S. Govt. Printing Office).

Boyce, R. E., 1981. Electrical resistivity, sound velocity, thermal conductivity, density-porosity, and temperature, obtained by laboratory techniques and well logs: Site 462 in the Naru Basin of the Pacific Ocean. In Larson, R. L., Schlanger, S. O., et al., Init. Repts. $D S D P, 61$ : Washington (U.S. Govt. Printing Office), 743-761.

Bryant, W. R., Deflache, A. P., and Trabant, P. K., 1974. Consolidation of marine clays and carbonates. In Inderbitzen, A. L. (Ed.), Deep-Sea Sediments: Physical and Mechanical Properties: New York (Plenum), pp. 209-244.
Duennebier, F., and Blackinton, G., 1980. A man-made hot spring on the ocean floor. Nature, 284:338-340.

Embley, R. W., Hobart, M. A., Anderson, R. N., and Abbott, D., 1983. Anomalous heat flow in the northwest Atlantic: A case for continued hypothermal circulation in 80-M.Y. crust. J. Geophys. Res., 88:1069-1074.

Erickson, A. J., and Hyndman, R. D., 1978. Downhole temperature measurements and thermal conductivities of samples, Site 396, DSDP Leg 46. In Dmitriev, L., Heirtzler, J., et al., Init. Repts. $D S D P, 46$ : Washington (U.S. Govt. Printing Office), 389-400.

Hyndman, R. D., Von Herzen, P., Erickson, A. J., and Jolivet, J., 1977. Heat flow measurements, DSDP Leg 37. In Aumento, F., Melson, W. G., et al., Init. Repts. DSDP, 37: Washington (U.S. Govt. Printing Office), 347-362.

Jaeger, J. C., 1965. Application of the theory of heat conduction to geothermal measurements. In Lee, W. H. K., (Ed.), Terrestrial Heat Flow: Washington (Am. Geophys. Union Monogr. 5), pp. $7-23$.

Langseth, M. G., Hyndman, R. D., Becker, K., Hickman, S. H., and Salisbury, M. H., 1984. The hydrogeological regime of isolated sediment ponds in mid-oceanic ridges. In Hyndman, R. D., Salisbury, M. H., et al., Init. Repts. DSDP, 78B: Washington (U.S. Govt. Printing Office), 825-837.

Larson, R. L., and Schlanger, S. O., 1981. Geological evolution of the Nauru Basin, and regional implications. In Larson, R. L., Schlanger, S. O., et al., Init. Repts. DSDP, 61: Washington (U.S. Govt. Printing Office), 841-862.

Morin, R., and Silva, A. J., 1984. The effects of high pressure and high temperature on some physical properties of ocean sediments. J. Geophys. Res., 89:511-526.

Parsons, B., and Sclater, J. G., 1977. An analysis of the variation of ocean floor bathymetry and heat flow with age. J. Geophys. Res., 82:803-827.

Schlanger, S. O., Jenkyns, H. C., and Premoli Silva, I., 1981. Volcanism and vertical tectonics in the Pacific basin related to global Cretaceous transgressions. Earth Planet. Sci. Lett., 52:435-449.

Uyeda, S., and Horai, K., 1981. Heat Flow measurements on Deep Sea Drilling Project, Leg 60. In Hussong, D. M., Uyeda, S., et al., Init. Rept. DSDP, 60: Washington (U.S. Govt. Printing Office), 789-802.

Yokota, T., Kinoshita, H., and Uyeda, S., 1980. New DSDP (Deep Sea Drilling Project) downhole temperature probe utilizing IC RAM (memory) elements. Bull. Earthquake Res. Inst. Tokyo, 54: 3441-462.

Zoback, M. D, and Anderson, R. M., 1983. Permeability, underpressures, and convection in the oceanic crust at DSDP Hole 504B. In Cann, J. R., Langseth, M. G, Honnorez, J., Von Herzen, R. P., White, S. M., et al., Init. Repts. DSDP, 69: Washington (U.S. Govt. Printing Office), 245-254.

Date of Initial Receipt: 2 July 1984

Date of Acceptance: 19 November 1984

\section{APPENDIX}

\section{Note Added by Co-Chief Scientists, October 15, 1985}

Recently we learned that an El Niño event late in 1982 affected sea level in the western equatorial Pacific (K. Wyrtki, personal communication, 1985). See Site 462 report (this volume) for comments about total depth of Hole 462A at the end of Leg $61(1068 \mathrm{~m})$ compared to apparent depth when reentered during Leg 89 (1071 m). The discrepancy may have resulted from inaccurate pipe measurements or sea level rise or both. If sea level had risen at Site 462 between 1978 and 1982 , the added pressure should be considered as a possible factor in the flow of seawater into the bore hole. 